\title{
Effect of Work Discipline, Work Motivation and Job Satisfaction on Employee Organizational Commitment in the Company (Case Study in PT. Dada Indonesia)
}

\author{
Anwar Prabu Mangkunegara ${ }^{1, *}$, Tinton Rumbungan Octorend ${ }^{2}$ \\ ${ }^{1}$ Department of Psychology, Faculty of Psychology in Mercu Buana University, Jakarta, Indonesia \\ ${ }^{2} \mathrm{PT}$. Dada Indonesia, Indonesia
}

Copyright $(\mathcal{C} 2015$ by authors, all rights reserved. Authors agree that this article remains permanently open access under the terms of the Creative Commons Attribution License 4.0 International License

\begin{abstract}
This study analyzed the influence of Work Discipline, Work Motivation and Job Satisfaction on Organizational Commitment employees in staffing levels. Object of this study is the level of staff employees at PT. Dada Indonesia. The research problem refers to the phenomenon of the data on the PT. DADA INDONESIA, which indicated the level of absenteeism or employee absenteeism average - average to reach $4-5$ percent. The problem that arises is: how to improve employee Organizational Commitment. A modeling has been constructed and 4 (four) research hypotheses have been formulated. This researched used Proportional Random Sampling. The study used 148 respondents and the overall level of staff respondents were employees of PT. Dada Indonesia. The results of this study show them that Work Discipline has positive effect on Organizational Commitment. Work Motivation has positive effect on Organizational Commitment. Job satisfaction has positive influence on Organizational Commitment. Work discipline, work motivation and job satisfaction has positive influence on Organizational Commitment.
\end{abstract}

Keywords Work Discipline, Work Motivation, Job Satisfaction, Organizational Commitment

\section{Introduction}

\section{Background of Study}

Increasingly intense levels of competition resulting business organizations are faced with the challenge to be able to maintain viability. The success of an organization or an organization is influenced by Organizational Commitment owned by an employee to perform duties in accordance with the responsibilities assigned to them.
Employees are an important resource for the organization, because it has the talent, energy, and creativity that is needed by the organization to achieve its objectives.

In order to enhance the Organization's commitment of employees, organizations need to focus on the interests of employees who have a wide range of needs. A professional employee cannot escape the fact that they are individuals who also have needs, wants, and expectations from work. The desire to meet this requirement will affect the motivation of the existing work on each individual to do everything better than the other in their efforts to achieve the goal.

In increased Organizational Commitment of employees, organizations should also enforce discipline of the workers, because the discipline of an employee getting the higher the performance shown by the employee, it can be seen from the level of their craft to carry out his responsibilities as an employee in a company their work.

In improving the organization of employee commitment, a good organization should look at the level of job satisfaction of employees. The reason why companies should look at the level of job satisfaction of the employees are more satisfied because of an employee in the work at the company where he worked, the higher the employee's desire to contribute to the full in order to increase company profit by running all over his responsibilities as an employee in the company with wholeheartedly.

Figures Organizational Commitment an employee in a company can be seen by looking at the total attendance of employees in the company over the past few months, and many other ways. In this case I use way of looking at the total employee absenteeism during the twelve (12) months in measuring employee Organizational Commitment in PT. Dada Indonesia. From the whole range of staff in PT. Dada Indonesia, the authors have overall attendance data Board Staff in the 12 (twelve) months which can be seen in the table below: 
Table 1. Employee Attendance in PT. DADA INDONESIA

\begin{tabular}{|c|c|c|c|c|c|c|c|c|c|c|c|c|c|}
\hline \multirow{2}{*}{ Name Section } & \multicolumn{12}{|c|}{ MONTH } & \multirow{2}{*}{ Total } \\
\hline & 1 & 2 & 3 & 4 & 5 & 6 & 7 & 8 & 9 & 10 & 11 & 12 & \\
\hline MARKETING & 26 & 26 & 12 & 19 & 16 & 28 & 36 & 12 & 30 & 26 & 33 & 29 & 293 \\
\hline $\begin{array}{c}\text { TEAM LEADER } \\
\text { (Embo, Printing, Cutting, } \\
\text { Packing, Sample) }\end{array}$ & 11 & 14 & 12 & 9 & 11 & 12 & 20 & 8 & 11 & 10 & 6 & 8 & 132 \\
\hline SPV & 9 & 18 & 4 & 6 & 6 & 9 & 9 & 2 & 15 & 1 & 13 & 15 & 107 \\
\hline EXPORT & 3 & 6 & 8 & 9 & 10 & 3 & 8 & 6 & 4 & 9 & 13 & 7 & 86 \\
\hline MECHANICAL & 4 & 2 & 3 & 5 & 2 & 4 & 9 & 6 & 14 & 4 & 4 & 7 & 64 \\
\hline DEVELOPMENT & 7 & 1 & 1 & 10 & 16 & 6 & 2 & 3 & 0 & 0 & 2 & 6 & 54 \\
\hline QUALITY CONTROL & 5 & 3 & 4 & 2 & 6 & 2 & 5 & 3 & 0 & 4 & 1 & 4 & 39 \\
\hline PURCHASING & 2 & 2 & 2 & 2 & 5 & 2 & 6 & 3 & 3 & 2 & 2 & 3 & 34 \\
\hline GENERAL STAFF & 5 & 4 & 2 & 3 & 0 & 2 & 5 & 2 & 2 & 2 & 4 & 3 & 34 \\
\hline QUALITY ASSURANCE & 4 & 2 & 3 & 0 & 5 & 1 & 0 & 0 & 3 & 1 & 4 & 2 & 25 \\
\hline COMPLIANCE & 1 & 2 & 6 & 1 & 1 & 3 & 1 & 0 & 1 & 2 & 1 & 1 & 20 \\
\hline HRD \& GA & 1 & 2 & 2 & 0 & 0 & 0 & 3 & 0 & 2 & 5 & 2 & 1 & 18 \\
\hline FINANCIAL & 1 & 0 & 0 & 0 & 0 & 1 & 3 & 0 & 2 & 2 & 1 & 0 & 10 \\
\hline \multirow{2}{*}{ Name Section } & \multicolumn{12}{|c|}{ MONTH } & \multirow{2}{*}{ Total } \\
\hline & 1 & 2 & 3 & 4 & 5 & 6 & 7 & 8 & 9 & 10 & 11 & 12 & \\
\hline TEAM LEAN & 1 & 1 & 0 & 2 & 1 & 0 & 0 & 0 & 0 & 1 & 1 & 2 & 9 \\
\hline IT & 0 & 0 & 0 & 1 & 0 & 1 & 0 & 1 & 0 & 0 & 0 & 0 & 3 \\
\hline
\end{tabular}

Source: Data Recap Attendance HRD PT. DADA INDONESIA

Based on the above table can be created around the Board table the percentage of absenteeism Staff at PT. DADA INDONESIA which can be seen as follows:

Table 2. Percentage of Employee Absenteeism in PT. DADA INDONESIA

\begin{tabular}{|c|c|c|}
\hline \multicolumn{1}{|c|}{ Per Section Work } & TOTAL & \% \\
\hline Name Section & 293 & 31.6 \\
\hline MARKETING & 132 & 14.2 \\
\hline TEAM LEADER & 107 & 11.5 \\
\hline SPV & 86 & 9.3 \\
\hline EXPORT & 64 & 6.9 \\
\hline MECHANICAL & 54 & 5.8 \\
\hline DEVELOPMENT & 39 & 4.2 \\
\hline QUALITY CONTROL & 34 & 3.7 \\
\hline PURCHASING & 34 & 3.5 \\
\hline GENERAL STAFF & 25 & 2.7 \\
\hline QUALITY ASSURANCE & 20 & 2.2 \\
\hline COMPLIANCE & 18 & 1.9 \\
\hline HRD \& GA & 10 & 1.1 \\
\hline FINANCIAL & 9 & 0.9 \\
\hline TEAM LEAN & 3 & 0.3 \\
\hline IT & & \\
\hline
\end{tabular}

Source: Data Recap Attendance HRD PT. DADA INDONESIA

From the table above it can be seen the reason why the total attendance marketing staff has the greatest number of employees due to the greatest number of the total staff in PT. DADA INDONESIA. Of the total percentage can be seen Organizational Commitment levels of employees in every area, and can also be investigated why there are differences sizable percentage of each field in the ranks of the staff in terms of organizational commitment. 
In addition to analyzing how much absenteeism of employees, the author tries to make a graph of each employee's absence for 5 years back, as can be seen in Figure 1:

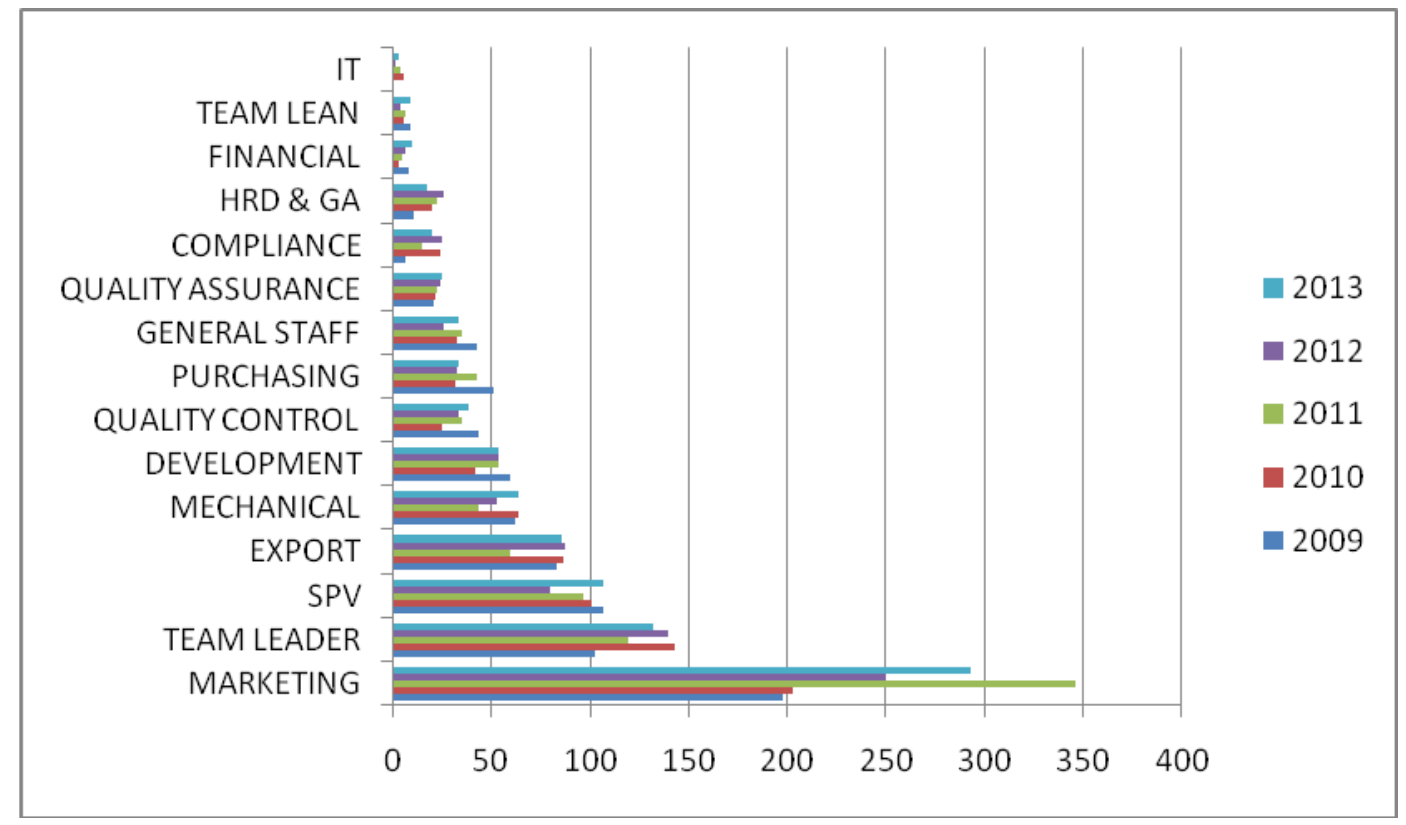

Figure 1. Employee Absence charts 2009 - 2013

In the above graph it can be seen that the absenteeism of employees in PT. DADA INDONESIA tend to fluctuate, in other words do not have a clear pattern is likely to go up or down, as can be seen in the graph, every year there are divisions increased absenteeism and some divisions were decreased absenteeism with no apparent pattern.

\section{Identification of Study}

From the data above, the writer wishes raises the issue of Organizational Commitment of employees in PT. DADA INDONESIA with knowing how motivated employees work in Company, in addition, the authors also wish to know how the discipline of employees at Company which is closely related to the commitment of the employees in the company, and the author also wishes to know how satisfied employees work at Company and its relation to the commitment of the employees in the company.

Organizational Commitment of employees in PT. DADA INDONESIA has several problems, among others, as follows:

a. Incompatibility expertise or skills that employees in the work.

b. Most employees are disciplined in carrying out its responsibilities.

c. Some employees feel less satisfied with the results of the work done.

d. Incompatibility compensation received from the company with his work and achievement.

\section{Formulation of Study}

Based on the description in the background and the identification problem, so the problem can be formulated in the following research: a. Is Work Discipline effect on Organizational Commitment.

b. Is Work Motivation effect on Organizational Commitment.

c. Is Job Satisfaction effect on Organizational Commitment.

d. Is Work Discipline, Work Motivation, Job Satisfaction on Organizational Commitment .

\section{Objective of Study}

Objective of this study as follow :

a. To know and analyze the effect of Work Discipline on Organizational Commitment.

b. To know and analyze the effect of Work Motivation on Organizational Commitment.

c. To know and analyze the effect of Job Satisfaction on Organizational Commitment.

d. To know and analyze the effect of Work Discipline, Work Motivation, Job Satisfaction on Organizational Commitment.

\section{Materials}

Discipline is essentially the ability to control himself in the form of not doing an action that does not conform and support something that has been created.

Some experts express opinions about the definition of labor discipline are as follows: Discipline is management action to enforce the standards organization.[9]. This means that the discipline of work can be interpreted as the implementation of management guidelines to strengthen the organization. Discipline of work is a tool used by managers 
to communicate with employees so that they are willing to change a behavior as an attempt to increase one's awareness and willingness to comply with all company regulations and norms prevailing social.[14]. Discipline of work is one's awareness and willingness to comply with all company regulations and norms in force. [5]. So it can be concluded that the discipline of work is an effort of the management organization of the company to implement or execute the rules or regulations that must be adhered to by all employees without exception.

Motivation is a condition or energy which drives the self-directed or directed employees to achieve organizational goals of the company. Mental attitude and positive pro employees to work situation is strengthening his motivation to achieve maximum work motivation. Motivation is a process that will determine the intensity, direction, and persistence of individuals in an effort to reach the target. [15]. Motivation is "a process which needs to encourage a person to perform a series of events that lead to the achievement of certain goals.[10]. When needs are met it will be achieved a satisfaction. A group of unsatisfied needs will cause tension, so that should be a series of activities to look for the achievement of specific objectives that can satisfy the needs of the group before, so that the tension is reduced ".Understanding motivation to work that the statement: "Work motivation is something that raises morale boost or is influenced by several factors, among others, boss, physical facilities, policies, rules, rewards and non-cash money services, types work and challenges "[16]. Work motivation is the driving force that giving one's work creates excitement that they want to work together, to work effectively, and integrated with all its resources to achieve satisfaction.[5]. Defines motivation as a process that determines the intensity, direction and persistence of individuals in an effort to reach the target. Although the general motivation associated with efforts toward any target, in the context of the organization, motivation focuses on the organization's goals in order to reflect the sole interest of employees against work-related behavior.[15]. Motivation as a driver or driver behavior towards the achievement of goals is a cycle that consists of three elements, namely the need (need), the urge to act and act (drives), and the desired objectives (goals). So more can be concluded that motivation is a series of encouragement, which is not only to others but also to himself. So through this impulse is expected to act towards the desired goal. Classify the several theories of motivation that includes the initial theory of motivation and contemporary theories of motivation. Early theories of motivation are the theory $\mathrm{X}$ and theory $\mathrm{Y}$ and theory of two factors. While contemporary theories include ERG theory, McClelland's theory of needs, cognitive evaluation theory, the theory of goal setting, reinforcement theory, the theory of drift (flow) and intrinsic motivation, equity theory and expectancy theory. In this study the theory of motivation that can be given attention because it is closely related to the achievement of the performance is the theory of hope. Expectancy theory says that employees are motivated to do a lot more effort if the employee believes these efforts will result in better performance assessment. Expectancy theory focuses on three relationships: (a) the relationship efforts - performance. Probability perceived by the individual who issued a number of specific measures that will drive performance. (b) The relationship of performance - reward. The extent to which the individual believes that performing at a particular level will encourage the achievement of the desired output. (c) The relationship benefits - personal objectives. To what extent remuneration meet the target organization or individual's personal needs and the potential attractiveness of the benefits for the individual. In meeting, their needs someone would behave in accordance with the encouragement owned and what is the underlying behavior, for it can be said that in a person there will be a force that leads to action.

Job satisfaction is basically something individual. Each individual has a different level of satisfaction varies according to the value system that applies to him. The higher the perceived assessment of the activity in accordance with the desires of the individual, the higher the satisfaction of the activity. Thus, satisfaction is an evaluation that describes someone on his feeling happy or not happy, satisfied or not satisfied at work. Some experts expressed opinions on the definition of job satisfaction are as follows: According Wexley and Yukl states that job satisfaction was: "Job satisfaction is the way employed feels about his or her job. [9]. It is a generalized attitude toward the job based on the evaluation of different aspect of the job. A person job reflects his attitude toward pleasant and unpleasant experience in the job and his expectations about future experiences ". This means that job satisfaction is one's feelings toward his work. Attitudes towards work that is based on the evaluation of the different aspects of the job attitudes towards work that describe the experiences pleasant or unpleasant in the work and expectations regarding future experience. Job satisfaction was: "Job satisfaction is the favorableness or unfavorable with employees view Reviews their work". [9]. It means it is a feeling of support or not support experienced by employees in the work. Job satisfaction is a pleasant emotional attitude and loves his job. This attitude is reflected by the morale, discipline, work. Job satisfaction enjoyed by the job, off the job, and a combination of inside and outside of work.[5]. Based on the above definitions can be concluded that job satisfaction is the way individuals feel the work resulting from any such individual to the various aspects contained in the job.

Organizational commitment is defined as: A strong desire to remain as members of a particular organization; The desire to strive to suit the organization; and certain beliefs, and acceptance of the values and goals of the organization.[8]. In other words, this is an attitude that reflects the loyalty of employees in the organization and ongoing process in which members of the organization expressed concern to the organization and the success and progress of sustainable. The general concern and the key 
objectives of the HR organizational unit is to look for the measurement can accurately estimate the commitment of workers and develop programs and activities that improve the organization's commitment. Further stated that extensive research studies in psychology and management is about the concept and role of organizational commitment (organizational commitment).[21]. These constructs linked to the importance of the resulting performance and turnover. When the construct of organizational commitment received much attention in the literature of psychology and management, it is also becoming important in fields related to technology and development, so that the management in this field began to focus attention on this organizational commitment construct. The notion of organizational commitment with respect to the opinions of Meyer and Allen, Curtis and Wright, and SGA, et.al. defines organizational commitment as a psychological state that characterizes employee relationship with the organization or implications that affect whether the employee will remain in the organization or not, were identified in three components: affective commitment, continuance commitment and normative commitment.[21]. Definition of organizational commitment is interesting, because the visits are psychological state employees to remain in the organization. And it feels very appropriate to analyze the organizational commitment of employees in a business organization or non-profit oriented organization.

\section{Methods}

Research that will do is to research the type of Quantitative. This type of study design uses Explanatory Survey. Explanatory Survey is a survey that is used to describe the relationship between two or more variables through hypothesis testing. The survey was conducted by taking a sample of the total population and the use of a questionnaire as a data collection tool. Furthermore, the method used descriptive and verification. Research descriptive method is a method that aims to describe, existing situation in the company based on facts and data collected then arranged systematically. Verification method is through the research evidence to test hypotheses descriptive research results with a statistical calculation, so it can be retrieved results show evidence that the hypothesis is accepted or rejected.

The population in this study is a whole range of staff who work in PT. INDONESIA DADA in the period 2013 to 2014, with total employees reached 257 employees. While the sample size of the authors using Proportional Sampling was calculated as follows:
Table 3. Sample Calculations

\begin{tabular}{|c|c|c|c|}
\hline No & Units & Population & Sample \\
\hline 1 & FINANCIAL & 5 & 5 \\
\hline 2 & HRD \& GA & 5 & 5 \\
\hline 3 & IT & 3 & 3 \\
\hline 4 & EXPORT & 17 & 8 \\
\hline 5 & SPV & 13 & 13 \\
\hline 6 & QUALITY CONTROL & 75 & 7 \\
\hline 7 & MARKETING & 15 & 87 \\
\hline 8 & QUALITY ASSURANCE & 18 & 9 \\
\hline 9 & MECHANICAL & 3 & 3 \\
\hline 10 & PURCHASING & 7 & 7 \\
\hline 11 & DEVELOPMENT & 4 & 4 \\
\hline 12 & COMPLIANCE & 54 & 27 \\
\hline 13 & TEAM LEADER (Printing, & 5 & 5 \\
\hline 14 & Tutting, Packing, Sample) & 7 & 7 \\
\hline 15 & GENERAL LEAN & 257 & 148 \\
\hline
\end{tabular}

Specification:

Data $\geq 10=$ the data divided by 2

Data $\leq 10=$ the data is taken entirely

In an effort to increase the commitment of its employees at work, then head of the company should strive to improve the power and passion of employees by increasing job satisfaction to employees. In addition to providing job satisfaction, employees must be motivated in their work. In general, satisfaction and motivation can appear simultaneously and correlated between the two. Employees who have the motivation and enthusiasm of work will work with feeling happy and satisfied and tried to work with the best. In addition, employees will consciously have discipline. Discipline employees must be applied correctly, so that any existing employees in the company can carry out the task and work well, to comply with existing regulations.

Sometimes these three factors occur simultaneously and interconnected to one another, so that at the same time also can affect employee commitment in working in a company. By analogy, if the employee has a high discipline, then the employee will do the job as well as possible and make every effort to avoid doing mistakes, work, so that the work will increase.

Based on the description above framework, it can be formulated research paradigm, namely that the work discipline, motivation, and job satisfaction can affect employee commitment, which is expressed in Figure 2 on the following framework.

The relationship between independent and dependent variables in this study is described in the following framework: 


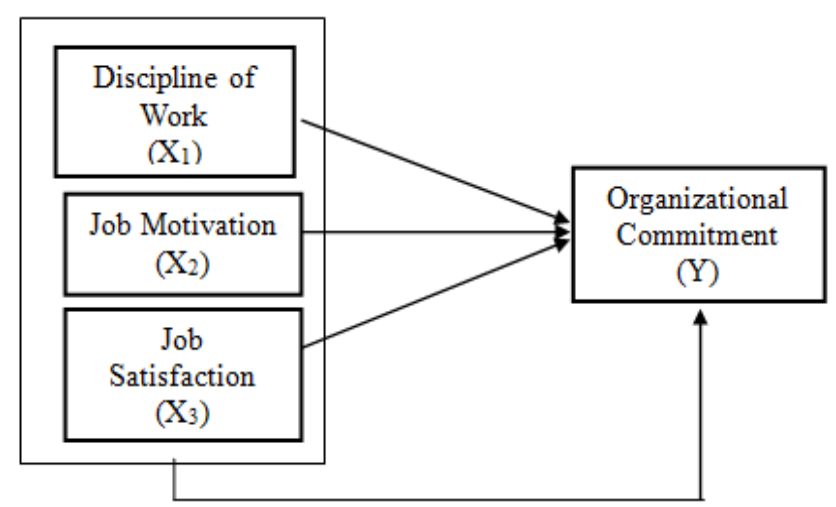

Figure 2. Theoretical Framework

Based on the above framework, the hypotheses of this study are as follows:

a. Influence of Organizational Commitment Work Discipline against employees in the company.

b. Influence of Work Motivation on Employee
Organizational Commitment in the company.

c. Influence of Job Satisfaction on Employee Organizational Commitment in the company.

d. Influence of Work Discipline, Work Motivation and Job Satisfaction on Employee Organizational Commitment in the company.

Based on the above framework, the hypotheses of this study are as follows: Influence of Work Discipline, Work Motivation and Job Satisfaction on Employee Organizational Commitment in the company.

\section{Results and Discussion}

Normality test results showed that the independent variables and the dependent have a normal distribution. To test for normality can be calculated with the formula Kolmogorov-Smirnov. Normality test calculations demonstrated the following results:

Table 4. Normality test results

\begin{tabular}{|c|c|c|}
\hline \multicolumn{3}{|c|}{ One-Sample Kolmogorov-Smirnov Test } \\
\hline & & Organizational commitment \\
\hline \multicolumn{2}{|c|}{$\mathrm{N}$} & 148 \\
\hline \multirow{2}{*}{ Normal Parameters } & Mean & 37.8243 \\
\hline & Std. Deviation & 7.96909 \\
\hline \multirow{3}{*}{ Most Extreme Differences } & Absolute & .086 \\
\hline & Positive & .080 \\
\hline & Negative & -.086 \\
\hline \multicolumn{2}{|c|}{ Kolmogorov-Smirnov Z } & 1.050 \\
\hline \multicolumn{2}{|c|}{ Assumptions. Sig. (2-tailed) } & .220 \\
\hline \multicolumn{3}{|c|}{$\begin{array}{l}\text { a. Test distribution is Normal. } \\
\text { b. Calculated from data. }\end{array}$} \\
\hline
\end{tabular}

Source: Calculation Results SPSS

Based on the table 4.above, the Kolmogorov-Smirnov known value of 1.050 while the significance value of 0.220 or $0.220>0.05$ then the data is expressed in normal distribution.

In addition to using the Kolmogorov-Smirnov value, the authors also look for normality based on the image histogram below: 


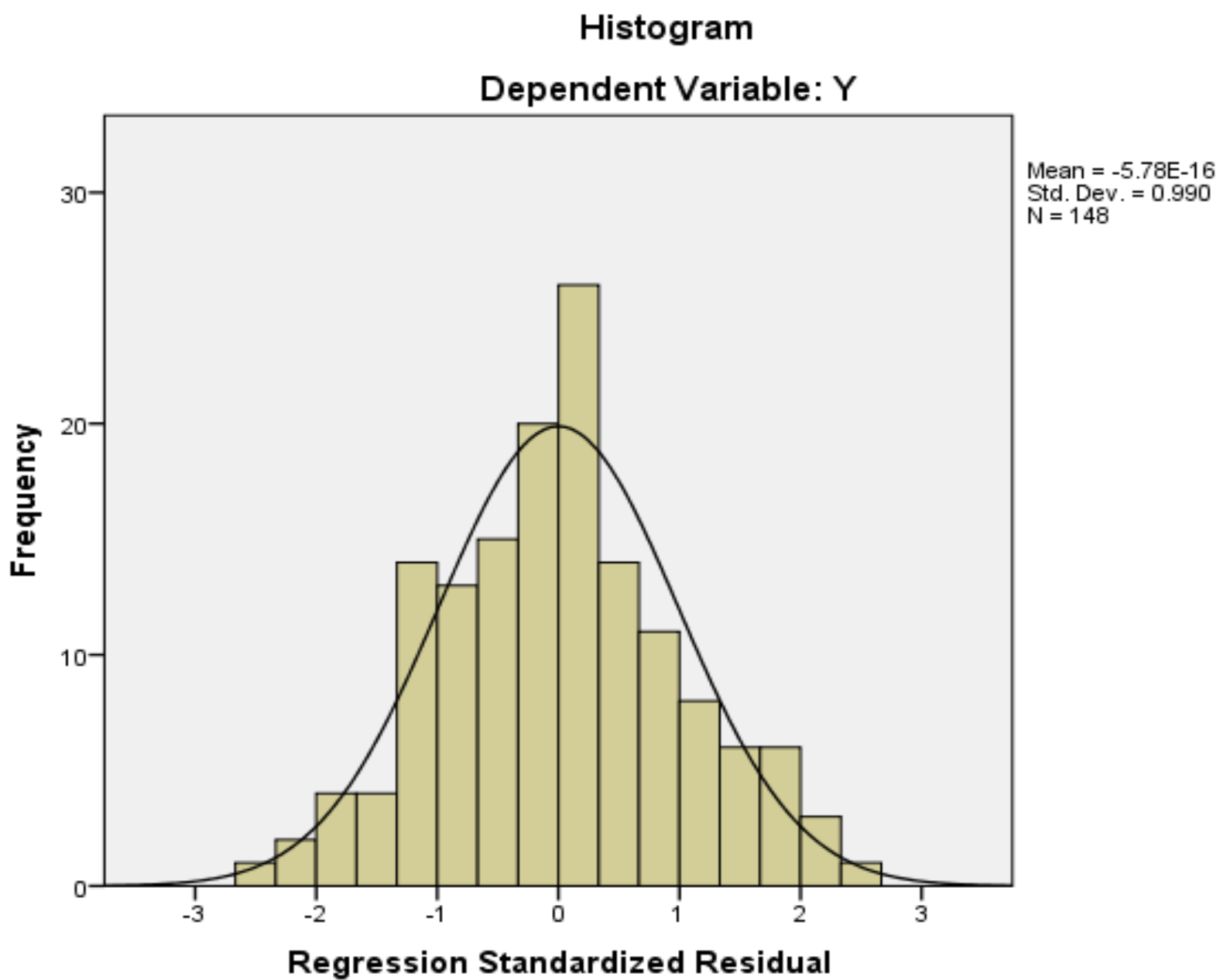

Figure 3. Histograms Normality

In the above histogram can be seen that the distribution pattern deviated to the right, it can be concluded that the data are normally distributed.

\section{Multicollinearity}

Multicllinearity test showed that the regression model is not impaired multicollinearity. It looks at the value of tolerance for the two variables do not exist independent variables that have a tolerance value of less than $10 \%$. VIF value calculation results show that no single variable has a value of VIF more than 10 . So it can be concluded that there is no multicollinearity between independent variables in the regression model. For multicollinearity test results can be seen in the following table 5:

Table 5. Multicollinearity Test Results

\begin{tabular}{|c|c|c|}
\hline Variable & Tolerance & VIF \\
\hline Work Discipline $\left(\mathrm{X}_{1}\right)$ & 0,663 & 1,508 \\
Job Motivation $\left(\mathrm{X}_{2}\right)$ & 0,744 & 1,345 \\
Job Satisfaction $\left(\mathrm{X}_{3}\right)$ & 0,543 & 1,840 \\
\hline \multicolumn{2}{|c|}{ Dependent Variable: Organizational } \\
\hline \multicolumn{2}{|c|}{ Commitment(Y) } \\
\hline
\end{tabular}

Source: Calculation Results SPSS

Based on the table above, for Work Discipline variable
(X1) has a value of $1.508 \mathrm{VIF}<10$, work motivation variable (X2) has VIF 1, 345<10 and Job Satisfaction variable (X3) has a VIF value of $1.840<10$ and thus The third variable in this study do not experience symptoms of multicollinearity because VIF $<10$ and a tolerance value $\leq 0.1$.

In addition to viewing by VIF and tolerance above, according Sugiyono (2014) says that to see if a study experienced multicollinearity is to look at the values of other calculations, such as the results of the F test, $t$ test results, and the results of test of $\mathrm{R}$ Square. In this research shows that the calculated $F$ value of 85.398 while the value of $F$ table 2.68 or $85.398>2,68$. Powered significance value of $0.000<0.05$ with the details of which can be seen in Table 5 .. While the $t$ value for $X 1$ of 5.087 , so that $t>$ table $(5.087>$ $1.960), \mathrm{t}$ value for $\mathrm{X} 2$ at 7.450 , so that $\mathrm{t}>\mathrm{t}$ table $(7.450>$ $1.960)$, and $t$ value of 3.822 for the $X 3$, so $t>t$ table $(3.822>$ 1.960), the results described in Table 5.. And research on $R$ Square test results, it appears that the value of $\mathrm{R}$ Square of 0.640 , wherein $\mathrm{R}$ Square value close to 1 . Where reference to the results of the research that has been qualified, it can be concluded that this study did not experience symptoms Multicollinearity.

This analysis is used to determine the influence of $\mathrm{X} 1$ (Work Discipline), X2 (Work Motivation) and X3 (job 
satisfaction) to variable Y (Organizational Commitment).

Table 6. Regression coefficients

\begin{tabular}{|c|c|c|c|}
\hline Model & $\begin{array}{c}\text { Regression } \\
\text { coefficients }\end{array}$ & $\mathrm{t}$ test & significance \\
\hline constant & 3,799 & 1,360 & 0,176 \\
\hline Work Discipline & 0,305 & 5,087 & 0,000 \\
\hline Work Motivation & 0,425 & 7,450 & 0,000 \\
\hline Job Satisfaction & 0,325 & 3,822 & 0,000 \\
\hline $\begin{array}{c}\text { Dependent } \\
\text { Variable:Organizational } \\
\text { Commitment }\end{array}$ & & & \\
\hline
\end{tabular}

Source: Calculation Results SPSS

Based on the regression equation derived table or a constant value $\alpha=3.799$

$$
\begin{gathered}
\mathrm{Y}=\alpha++\mathrm{BX} 2+\mathrm{BX} 1 \mathrm{BX} 3 \\
\mathrm{Y}=3.799+0.305+0.425 \mathrm{X} 1 \mathrm{X} 2 \mathrm{X} 3+0.325+\mathrm{e}
\end{gathered}
$$

The regression coefficient is positive above. This means that there is a positive effect of variable labor discipline, motivation variable work and job satisfaction on Organizational Commitment. The explanation of the above regression model can be described as follows:

$\alpha=3.799$ is the value of the intercept, which is the intersection of the regression line with the $\mathrm{Y}$-axis shows the Organizational Commitment $(\mathrm{Y})$ as the independent variable, namely labor discipline (X1), Work motivation (X2), and job satisfaction (X3) is zero or constant.

$\mathrm{b} 1=0.305$, meaning that each increase of labor discipline (X1) of the unit, it will increase Organizational Commitment (Y) of 0,305 units, if the independent variables, namely, work motivation (X2) and job satisfaction (X3) is considered constant.

$\mathrm{b} 2=0.425$, meaning that any increase in work motivation (X2) of the unit, it will increase Organizational Commitment (Y) amounted to 0,425 units, when the other independent variables, namely labor discipline (X1) and job satisfaction (X3) is considered constant.

$\mathrm{b} 3=0.325$, meaning that any increase job satisfaction (X3) of the unit, it will increase Organizational Commitment (Y) of 0325 units, if the other independent variables, namely labor discipline (X1) and work motivation (X2) is considered constant.

$\mathrm{T}$ value for $\mathrm{X} 1$ of 5.087 , so that $\mathrm{t}>\mathrm{t}$ table $(5.087>1.960)$. By taking a significance level based on the calculation of SPSS acquired $0,000<0,05$. Based on these results it is known that $\mathrm{Ha}$ is accepted, it means working discipline positive effect on organizational commitment significantly.

$\mathrm{T}$ value of 7.450 for the $\mathrm{X} 2$, so $t>t$ table $(7.450>1.960)$. By taking a significance level based on the calculation of SPSS acquired $0,000<0,05$. Based on these results it is known that $\mathrm{Ha}$ is accepted, it means work motivation positive effect on organizational commitment significantly.

$\mathrm{T}$ value of 3.822 for the $\mathrm{X} 3$, so that $\mathrm{t}>\mathrm{t}$ table (3.822> 1.960). By taking a significance level based on the calculation of SPSS acquired $0,000<0,05$. Based on these results it is known that $\mathrm{Ha}$ is accepted, it means a positive effect on job satisfaction significantly Organizational Commitment.

F Test is intended to test the hypothesis to 4 in this study, which reads: Discipline Work, Work Motivation, Job Satisfaction and Organizational Commitment affect the staff level employees of PT. DADA INDONESIA. Based on the calculations have been done, so in this study are presented the results of the calculation of the F test in the table below:

Table 7. F Test

\begin{tabular}{|c|c|c|c|c|c|c|}
\hline \multicolumn{7}{|c|}{ ANOVA $^{\text {b }}$} \\
\hline \multicolumn{2}{|c|}{ Model } & $\begin{array}{c}\text { Sum of } \\
\text { Squares }\end{array}$ & df & Mean Square & F & Sig. \\
\hline \multirow{3}{*}{1} & Regression & 5976.307 & 3 & 1992.102 & 85.398 & $.000^{\mathrm{a}}$ \\
\cline { 2 - 7 } & Residual & 3359.126 & 144 & 23.327 & & \\
\cline { 2 - 7 } & Total & 9335.432 & 147 & & & \\
\hline
\end{tabular}

a. Predictors: (Constant), Job Satisfaction, Work Motivation, Discipline b. Dependent Variable: Organizational Commitment

Source: Calculation Results SPSS

Based on the table above 7, it can be a sense that the calculated $F$ value of 85.398 while the value of $F$ table 2.68 or $85.398>2,68$. Powered significance value of $0.000<0.05$. These results reflect that Work Discipline, Work Motivation and Job Satisfaction positive and significant impact on Organizational Commitment staff level employees of PT. DADA INDONESIA.

Next, the authors will summarize the results of the calculation of the correlation coefficient (r) to determine the dimensions of the independent variables are the most dominant influence on the dependent variable dimensions. The larger the value of Pearson correlation, the stronger its effect relationship and greatly to increase the dimensions of the dependent variable. The results of calculation of the correlation coefficient (r) between dimensions can be seen in the following correlations: 
Table 8. Matrix of the Correlation between Dimensions

\begin{tabular}{|c|c|c|c|c|}
\hline \multirow{2}{*}{ Variable } & \multicolumn{2}{c|}{ Organizational Commitment } \\
\hline \multirow{4}{*}{ Work discipline } & Dimensions & Affective & Normative & Rational \\
\cline { 2 - 5 } & frequency of attendance & 0.090 & 0.683 & $0.957^{*}$ \\
\cline { 2 - 5 } & Obedience At Work Standard & -0.317 & -0.725 & 0.109 \\
\cline { 2 - 5 } & Obedience In Regulation & -0.006 & -0.201 & -0.193 \\
\cline { 2 - 5 } & Work ethics & -0.866 & -0.064 & 0.189 \\
\hline \multirow{4}{*}{ Work Motivation } & physiological needs & 0.101 & 0.721 & $0.894^{*}$ \\
\cline { 2 - 5 } & Security needs & -0.200 & -0.913 & -0.712 \\
\cline { 2 - 5 } & Award needs & 0.456 & 0.049 & -0.674 \\
\cline { 2 - 5 } & Social needs & 0.456 & 0.049 & -0.674 \\
\hline \multirow{7}{*}{ Self-Actualization Needs } & 0.456 & 0.049 & -0.674 \\
\hline \multirow{7}{*}{ Job Satisfaction } & salary & $-1.000^{* *}$ & $1.000^{* *}$ & $1.000^{* *}$ \\
\cline { 2 - 5 } & The work itself & -0.538 & $-1.000^{*}$ & -0.973 \\
\cline { 2 - 5 } & promotion & $-1.000^{* *}$ & -0.554 & -0.327 \\
\cline { 2 - 5 } & co-workers & 0.837 & 0.013 & -0.115 \\
\cline { 2 - 5 } & work environment & 0.837 & 0.013 & -0.115 \\
\hline & Satisfaction with the boss & -0.741 & 0.149 & 0.392 \\
\hline
\end{tabular}

Source: SPSS Count Results are summarized by the author (2014)

A reference to determine the level of correlation between the dimensions used table-level relationships based on interval coefficient quoted as shown in Table 9.

Table 9. Interpretation of the correlation coefficient $\mathrm{R}$ value

\begin{tabular}{|c|c|}
\hline Interval Coefficient & Correlation \\
\hline $0,80-1,000$ & very strong \\
\hline $0,60-0,799$ & strong \\
\hline $0,40-0,599$ & strong enough \\
\hline $0,20-0,399$ & low \\
\hline $0,00-0,199$ & very low \\
\hline
\end{tabular}

Source: Riduwan. (2006: 280)

Results of correlation analysis in Table 9 concluded that all dimensions variable Work Discipline, Work Motivation and Job Satisfaction coefficient values between 0.80 to 1.000 , meaning that these three variables have a relationship that is 'very strong' on Employee Organizational Commitment.

This section will discuss the results of research that has been done in PT. Dada Indonesia. From the results of linear regression calculation of the results of research on the Discipline of Work and Organizational Commitment can be shown that the $t$ value for X1 (Work Discipline) of 5.087, so that $\mathrm{t}>\mathrm{t}$ table (5.087>1.960). By taking a significance level based on the calculation of SPSS acquired $0,000<0,05$. Based on these results it is known that Ha is accepted, it means Work Discipline positive effect on Organizational Commitment significantly. And we can see also, as stated that the purpose of the Working Discipline employees who say that the employee is able to produce high productivity in accordance with the expectations of the organization, both in the short term and long term it is in need of values Commitment strong organization both affective, normative, and continuous. As stated in a previous study conducted by researchers. $[2,11,13]$. Where in the journal - the Journal said that the Work Discipline significantly influence Organizational Commitment. From the results of these studies have implications for PT. Dada Indonesia that to further improve the organizational commitment of employees, the company should further improve the discipline of employees, both in terms of attendance, enforcement of regulations and increased labor standards, so that will achieve maximum organizational commitment within the staff level employees. From the results of linear regression calculation of the results of research on Work Motivation and Organizational Commitment can be shown that the $t$ value for X2 (Work Motivation) of 7.450, so that $t>$ $t$ table $(7.450>1.960)$. By taking a significance level based on the calculation of SPSS acquired $0,000<0.05$. Based on these results it is known that $\mathrm{Ha}$ is accepted, it means a positive effect on work motivation significantly Organizational Commitment. And can we also see as suggested by Robbins (2008) which defines motivation as a process that determines the intensity, direction and persistence of individuals in an effort to reach the target. Motivation Although commonly associated with efforts toward any target, in the context of the organization, motivation focuses on the organization's goals in order to reflect the sole interest of employees against work-related behavior. Then the employee is in desperate need of values Organization strong commitment both affective, normative, and continuous. As stated in a previous study conducted by researchers. $[3,6,18]$. Where in the journal - the Journal said 
that the motivation Work significantly influence Organizational Commitment. From the results of these studies have implications for PT. Dada Indonesia that to further improve the organizational commitment of employees, the company should further improve work motivation employees, either by providing fair wages, provide benefits for employees, providing a sense of security and comfort in work, providing the opportunity for employees to actualize himself, as well as rewards for employees who excel, so that will achieve maximum organizational commitment within the staff level employees. From the results of linear regression calculation of the results of research on Job Satisfaction and Organizational Commitment can be shown that the $\mathrm{t}$ value for $\mathrm{X} 3$ (job satisfaction) of at 3.822, so that $t>t$ table (3.822> 1.960). By taking a significance level based on the calculation of SPSS acquired $0,000<0.05$. Based on these results it is known that $\mathrm{Ha}$ is accepted, it means a positive effect on job satisfaction significantly Organizational Commitment.[19]. And we can see also, as stated that job satisfaction impacts need to be monitored by linking the generated output, such as: 1) Job Satisfaction with Productivity, 2) Job Satisfaction with turnover, 3) Job Satisfaction with attendance, and 4) Job Satisfaction with other effects such as the physical-mental health, learning a new job and the ability to work accidents, to be able to produce outputs before the workers desperately need the values of a strong organizational commitment both affective, normative, and continuous. As stated in a previous study conducted by researchers.[1,4,7,12]. The Journal said that job satisfaction significantly influence Organizational Commitment. From the results of these studies have implications for PT. Dada Indonesia that to further improve the organizational commitment of employees, the company should further improve the sense of satisfaction in working within their employees, either by providing appropriate salary, provide jobs according to the workload of employees, providing opportunities for employees who excel for improve career and capabilities within the employee, improve the comfort of work for employees with due regard to the environment in which the employee works, as well as the boss for more attention to his subordinates so that subordinates feel more appreciated and comfortable in working together to improve the performance of the company, when all aspects of the above can be met then it will achieve maximum organizational commitment within the staff level employees. From the results of linear regression calculation of the results of research on Work Discipline, Work Motivation and Job Satisfaction on Organizational Commitment can be shown that the $t$ value for X1 (Work Discipline) of 5.087, so that $\mathrm{t}>\mathrm{t}$ table (5.087> 1.960), $t$ value for $X 2$ (Work Motivation) of 7.450, so that $t>$ $\mathrm{t}$ table $(7.450>1.960)$, and the $t$ value for $\mathrm{X} 3$ (job satisfaction) of amounting to 3.822 , so that $\mathrm{t}>\mathrm{t}$ table $(3.822>1.960)$. By taking a significance level based on the calculation of SPSS acquired $0,000<0.05$. Based on these results it is known that $\mathrm{Ha}$ is accepted, it means Discipline Work, work motivation and job satisfaction has positive influence on Organizational
Commitment significantly. This implies that in order to further enhance the Employee Organizational Commitment in PT. DADA INDONESIA, then the company should pay attention Frequency of presence of employees each month and pay more attention to the salaries of employees who work in PT. DADA INDONESIA.

\section{Conclusions}

Based on the results of research and discussion that has been done, so in this study presented the following conclusions: Work Discipline, work motivation and job satisfaction of employees at PT. Dada Indonesia that to further enhance the Employee Organizational Commitment, then the company should pay attention Frequency of presence of employees each month and pay more attention to the salaries of employees who work in PT. Dada Indonesia.

On the results of research conducted at PT. Dada Indonesia, dimensions variable frequency Attendance at Work Discipline has become a high-dimensional criteria, it gives the impression that the level of attendance of employees Level staff has been very good and need to be maintained by means of spur employees to be more disciplined present in the workplace and reduce the number of employees in the absence of any specific time.

In the results of research conducted at PT. Dada Indonesia, dimensions variable Physiological Needs in Work Motivation has been a high dimensional criteria, it gives the impression that self-motivation every employee has been quite good and need to be improved again by providing basic needs to the entire employee includes adequate rest, salary according to the needs of employees and provide adequate benefits that employees are encouraged to provide optimal performance in order to achieve organizational goals.

In the results of research conducted at PT. Dada Indonesia, dimensions variable salary in job satisfaction has been high dimensional criteria, it gives the impression that the level of satisfaction in the work of each employee in the PT. Dada Indonesia has been quite good and need to be improved again, by providing the basic needs of the entire employee includes salary in accordance with the needs of employees and provide overtime pay in accordance with the number of hours that the employee has been sacrificed in completing tasks that employees are encouraged to provide optimal performance in order to achieve organizational goals, but the company should be a little cautious in increasing the salaries of employees, because there is the possibility that employees Organizational Commitment in terms of Affective contradicts the results of the study, it can be circumvented by increasing employee satisfaction and the work environment coworkers who owned the employee.

The existence of a relationship and influence Work Discipline, Work Motivation and Job Satisfaction on Organizational Commitment of employees at PT. Dada Indonesia can be taken into consideration for the company to increase the Organizational Commitment. Based on the 
conclusions that have been described previously by increasing Discipline Work, work motivation and job satisfaction will affect the improvement of Organizational Commitment, it shows the PT. Dada Indonesia can increase employees Organizational Commitment to enhance the flavor of Work Discipline, Work Motivation and Job Satisfaction of employees by means of the company should pay attention Frequency of presence of employees each month and pay more attention to the salaries of employees who work in PT. Dada Indonesia.

\section{REFERENCES}

[1] Adekola. 2012. The Impact of Organizational Commitment on Job Satisfaction: A Study of Employees at Nigerian Universities. International Journal of Human Resource Studies, 2.2, pp : 18

[2] Asil., Pour., Javaheri. 2013. Surveying the relationship between preservation and maintenance factors of human resources with organizational commitment in Iranian Oil Contractors. International Journal of Agriculture and Crop Sciences, 5.19 , pp: 2255-2261.

[3] Bang,. Ross,. Reio,. 2013. Motivation to organizational commitment of volunteers in non-profit sport organizations. The Journal of Management Development, 32.1. pp: 96-112.

[4] Folkman. 2011. Employee Commitment. Leadership Excellence .28.4, pp: 18 .

[5] Hasibuan, M.S.P. 2010, Manajemen Sumber Daya Manusia, PT. BumiAksara, Jakarta.

[6] Iranmanesh,. Fuladvand,. Ameri,. Bahrampoor,. 2014. Iranian Nurses' Organizational Commitment and Job Motivation. Asian Journal of Nursing Education and Research, 4.2, pp: 189-194.

[7] Karim., R. 2012. Impact of Job Satisfaction, Perceived Organizational Justice and Employee Empowerment on Organizational Commitment in Semi-Government Organizations of Pakistan. Journal of Business Studies Quarterly, 3.4, pp: 92-104.
[8] Luthans, 2006.PerilakuOrganisasi. Diterjemahkan olehVivin Andika Yuwono dkk.EdisiPertama, PenerbitAndi, Yogyakarta.

[9] Mangkunegara,A.A,A. 2011. Manajemen Sumber Daya Manusia Perusahaan, Remaja Rosdakarya, Bandung.

[10] Munandar,A.S, Sjabadhyni,B. \& Wutun,Rufus Patty. 2004. Peran Budaya Organisasi dalam Peningkatan UnjukKerja Perusahaan. Depok :Penerbit PIO Fakultas Psikologi UI.

[11] Newell. 2012. Progressive Discipline Government Executive ,44.5 . pp: 39.

[12] Newman., S. 2012. Organizational rewards and employee commitment: a Chinese study. Journal of Managerial Psychology, 27.1, pp : 71-89.

[13] Pacitti. 2011. Efficiency Wages, Unemployment, And Labor Discipline. Journal of Business \& Economics Research, 9.3, pp: $1-10$.

[14] Rivai, V. 2011. Manajemen Sumber Daya Manusia untuk Perusahaan: dari Teori ke Praktik, Raja Grafindo Persada, Jakarta.

[15] Robbins, P. S.\& Judge, T. A. 2008. PerilakuOrganisasi. Edisi 12.Jilid 1.Alih Bahasa Diana Angelica dkk. Jakarta: Salemba Empat.

[16] Samsudin, S. 2006. Manajemen Sumber Daya Manusia, cetakan ke-1 Bandung: Pustaka Setia. Suwanto\&Priansa,

[17] Doni J. 2011. Manajemen Sumber Daya Manusia Dalam Organisasi Publik \& Bisnis.Bandung: Alfabeta.

[18] Tella,.Ayeni,.Popoola,. 2007. Work Motivation, Job Satisfaction, and Organisational Commitment of Library Personnel in Academic and Research Libraries in Oyo State, Nigeria. Library Philosophy and Practice (e-journal).

[19] Triton, PB. 2009. Mengelola Sumber Daya Manusia. Cetakan Pertama. Penerbit Oryza. Yogyakarta.

[20] Yuwalliatin, S. 2006. Pengaruh Budaya Organisasi, Motivasi Dan Komitmen Terhadap Kinerja Serta Pengaruhnya Terhadap Keunggulan Kompetitif Dosen UNISULA Semarang. EKOBIS. Vol 7. No 2. Hal: 241-256.

[21] Zurnali, C. 2010. Knowledge Worker: Kerangka Riset Manajemen Sumber Daya Manusia Masa Depan, PenerbitUnpad Press, Bandung. 